ACTA UNIVERSITATIS LODZIENSIS

FOLIA LITTERARIA POLONICA 6(36) 2016

http://dx.doi.org/10.18778/1505-9057.36.03

Piotr Łuszczykiewicz

\title{
The Scandalmonger: Julian Tuwim
}

\author{
Until enthusiasts, those who survived, \\ Tuwim was to meet at the secret political police ball \\ To close the flaming ring \\ And on, as always, went the Senator's ball \\ Czesław Miłosz, A Treatise on Poetry
}

Not many moral attitudes in Polish literature are as ruthless as the one which pertains to Tuwim in Czesław Miłosz's famous Treatise on Poetry. I have to be honest and say that through years' worth of reading Tuwim's works I have attempted to repress this phrase. Well, it was impossible, the most loved childhood poet, passionately recited in elementary school and later secondary school, the genius who wrote Ball at the Opera, the work that I wrote my master's thesis on - that he was to remain in the collective consciousness as a participant of UB (secret political police) balls. Indeed, Irena Krzywicka had written about this, but her gossipy Confessions of a debaucherer with tons of unconfirmed information were not exactly convincing. Speaking about Miłosz, the great literary scholar, Edward Balcerzan, once said to me uneasily, "One can say about another that he works for the UB only when they meet at the department's cash desk". However, more recent books on Tuwim, like the excellent biography by Mariusz Urbanek ${ }^{2}$, tell us to go back to the difficult thought and ask not whether or not the poet went to the balls organized by the UB, but why he would go to them.

I think that today the key to a comprehensive personality of the author of Kwiaty Polskie is the early, little utilized period of his life and creative work. Psychologists would dig even deeper, into little Julian's first years and the atmosphere of a polonized Jewish home with a father who was lost in life in a way one gets lost

\footnotetext{
* Prof. dr hab., e-mail: pluszcz@amu.edu.pl, Department of Media and Communications, Institute of Polish Philology, Faculty of Polish and Classical Philology, Adam Mickiewicz University in Poznan, 61-701 Poznan, 10 Fredry Street.

${ }^{1}$ Cz. Miłosz, Traktat poetycki (1957), in: Wiersze, vol. 2, second edition, Wydawnictwo Literackie, Cracow 1986, p. 14.

${ }^{2}$ See M. Urbanek, Tuwim. Wylękniony bluźnierca, Wydawnictwo Iskry, Warsaw 2013.
} 
in Bruno Schulz's Cinnamon Shops, along with an overprotective, defeatist and depressive mother who spread her visions of Julian's imminent harm. When it comes to his paradoxical choices in the future, the decisive event seems to be a school protest in 1905. Despite his mother's insisting, young Tuwim does not take part in it. He goes to school and sits at a desk along with a handful of Polish and Russian middle schoolers. From that moment on, he is labelled a strikebreaker, among other more derogatory terms. The immense stigma of exclusion will forever leave an imprint on his psyche, like a massive black mouse on the cheek, which will be called a traitor's rat by political opponents years later. This will surely determine his future behaviour and attitudes. Meanwhile, young Julek, living and growing in Lodz, begins succeeding as a provider of cabaret pieces, while trying his hand as a poet. This is where two important matters come up. Writing for cabaret, Tuwim develops a brilliant way of gaining an audience, one which he will later use in his well known monologues and songs. He criticizes in a way which causes all the criticized to believe that the criticism does not pertain to them, but to their neighbours or competitors. He mocks swindlers by saying that they are worried about the end of the war, because it means an end to deals with the army; he makes fun of the upstarts and their wives, saying that they are gaining goods but with no taste whatsoever. At the same time he takes his "high poetry" for evaluation to the great poets of the time: Bolesław Leśmian and Leopold Staff. This is where a surprise comes: Leśmian, who later admits to never having opened the young man's notebook, is dismissive in his judgement, while Staff, who was generally uncontrollably enthusiastic about debutants, also shown forty years later with Tadeusz Różewicz, received Tuwim's poetry enthusiastically. Although acknowledged by Staff, Tuwim knows that climbing the poetic Parnassus will not be easy, that the path is narrow and steep, competition plentiful and there is a crowd at the peak itself. He will apply a method which seems to be against his timid nature, a compensative strategy: bold provocation, a game set for scandal. This is how I understand the publication of Spring in "Pro Arte et Studio", a monthly student magazine at the University of Warsaw, where Tuwim studies after moving to Warsaw.

Into dim lawns, to the alleys,

On a bench, you dogblooded, On the grass,

Go and make brats for Poland

Writhe, you dogblooded, writhe

Drink up in street corner taprooms,

Scatter 'round more of them "bachelor's diseases"!

J. Tuwim, Spring. Dithyramb

${ }^{3}$ J. Tuwim, Wiersze zebrane, vol. I, Czytelnik, Warsaw 1975, pp. 140-141. 
The somewhat ordered scandal becomes reality, the magazine's editorial office falls apart, and the Skamandrites take over the magazine after the palace revolt. This is an undoubted gain. There are, however, losses: University of Warsaw professors are outraged, students and parents protest, poets - sometimes Tuwim's peers - cease cooperation with the paper demonstratively. He himself gains the label of a depraver of youth, a proclaimer of licentiousness, debauchery, heat and promiscuity. There is also the more dangerous label of the Jewish pornographer. The Dithyramb Spring, especially after being delivered from the stage of "Pod Pikadorem" ("Under the Picador") - a poetry cafe, gains a nationwide reception, singing praise to Dionysian revelry, but also showing the dark side of the cult. Tuwim, with awe and horror, as well as irony and sarcasm, begins to agree with the crowd he was always afraid of. In a naturalistic, vitalistic and biological or even physiological sense, Tuwim has also found a truth, but what a bitter truth it was.

And so Tuwim's great, promotional scandal panned out well, although not without a personal cost to the poet, who quiets down for some time in his fury to enjoy the well-deserved praise for poetry collections which were indeed great, such as In Lurking for God, The Dancing Socrates or Seventh Autumn. He is also enjoying married life with his beloved Stefania Marchew, whose hometown will always remain on the pages of Tuwim's poetry (At the Round Table) and in the sound of Ewa Demarczyk's song (Tomaszów). But this time history will come for what is hers. A crime committed in 1922 by a right-wing fanatic in Warsaw's Zachęta Gallery must receive a poetic reply. The well-known poem, The Funeral of President Narutowicz will sound with true, yet provocative words:

On your chest a cross you bore, but a browning in your pocket.

You formed an alliance with God, but made a pact with the murderer.

J. Tuwim, The Funeral of President Narutowicz ${ }^{4}$

In 1923, Tuwim publishes the poem To the Generals in "Robotnik" (The Worker) - a periodical of peculiar nature, which was tied to Józef Piłsudski initially, but accused of Bolshevism in free Poland.

You - a red lapel for slaughter

For murder, rape, and setting fire

We - our naked breast tear open

Our bare hearts as scarlet lapels

J. Tuwim, To the Generals ${ }^{5}$

\footnotetext{
${ }^{4}$ Ibidem, p. 331.

${ }^{5}$ Ibidem, p. 288.
} 
A massive scandal erupts, Piłsudski's legionaries feel offended. Some of the opinions voiced claim that here is a Jew who disrespects the honour of Polish officers. Tuwim is no longer just a "Jewish pornographer" as he was when he published Spring, but a "dangerous Jehova". To the Generals was very arty in its description, depicting Poland as the homeland of poets, and passers-by lost in thought as the generals of society. The poem was, instead, understood as an unprecedented attack on those who brought the country freedom in 1918, and defended this freedom in 1922 by fighting the Bolsheviks. It is no wonder then, that Tuwim was being sent off to Moscow in a hurry, his literary activities were disturbed, and if not for the intervention of General Wieniawa - Długoszewski, the adjutant of Marshal Piłsudski and an important character of the interwar period, the author would never have publicly scrambled out of this harassment.

This attack on Tuwim was staved off by the great Wieniawa: the next, however, couldn't be. In 1929, also in "Robotnik", the poet publishes a poem called To the simple man:

When they call on you: "Shoulder arms!"

That oil welled up in some ground somewhere

And brought about a ton of money;

That their accounts no longer add up,

And they sniffed out a fuller cash box

Or they have sights set, these fat swindlers,

On a higher duty tax on cotton.

Blast your rifle at cobblestone!

You get to bleed, they get the oil!

And from one capital to the other

Call out, be heard, defend your toil:

"Leave out your lies, dear noblemen!"

J. Tuwim, To the Simple Man ${ }^{6}$

A scandal of enormous proportions erupts. Due to the nature of this publication, I cannot quote the accusative words directed at the author. When reading this poem, I myself think that it was not false at the end of the twenties, the dawn of the Great Depression, when deliverance from unemployment, inflation, and social unrest was sought in military conflict which could drive the economy and ensure demand. Yet the same passage read in the context of 1939 must sound terrible. The demotivating, destructive wording of: "blast your rifle at cobblestone!" Especially when compared with Władysław Broniewski's famous phrase: "Bagnet na broń! Trzeba krwi!" (“Bayonets on! We need blood!) - doesn’t sound right and

\footnotetext{
${ }^{6}$ J. Tuwim, Wiersze zebrane, vol. 2, p. 178.
} 
is very difficult to defend. Wieniawa said that for such a poem Tuwim would get sentenced in the Soviet realm to at least 10 years of Siberia. Staff joked that assonances are no good, that he had always warned that they will only cause trouble, and that full rhymes would be better?

It was not a laughing matter, though. The poem was seen as anti-Polish, wicked, treacherous to the Fatherland and, lastly, plain stupid. Some, like Ferdynand Goetel, the president of the Union of Polish Writers, postulated that Tuwim should be removed from school books, and one renowned professors (later appearing in the text of Catujcie mnie wszyscy w dupe (Kiss this arse of mine) as "profesor cy Wileński") called Tuwim a "kikey Mickiewicz".

Tuwim responded ruthlessly. In one of his epigrams, Na jednego endeka co na mnie szczekat (To one National Democrat who barked at me) he replied harshly:

You waited in vain for me to write you back,

I won't flick your nose nor will you get a smack.

I won't even say that a dog fucked your arse

For to the dog it would be a mesalliance.

\section{J. Tuwim, On one ND who barks at $m e^{9}$}

He defended himself to the best of his skill, and his skills were impressive. But the truth is that around 1936 he felt that there was no place for him in Poland. What's worse, he felt there was no place for him in Europe. Fascism had won, Hitler, Franco and Mussolini were in power.

At the same time, to fight for the people's hearts and minds, Communism was rising in the USSR (drenched in blood, but who wrote about it then?). It was also hugely popular in France, but in Poland it was suppressed in the name of national security.

The Polish Peace Congress of 1936 was an event with a clearly communist background. We should also mention that Józef Piłsudski had died the year before and the National-Radical Camp of Bolesław Piasecki was active.

In the summer of 1936 Julian Tuwim writes his opus magnum: Ball at the Opera. Its fragments are published by the press, again mainly in "Robotnik", the whole piece circulates in copies and becomes a bible of the young, communising poets. Tuwim doesn't want to publish the work separately, maybe for the sake of his public, political and material life. In any case, it doesn't happen anytime soon; the full version of the poem is not released until as late as 1982 .

\footnotetext{
${ }^{7}$ M. Urbanek, op. cit., p. 104.

${ }^{8}$ See i.a. ibidem, pp. $121-139$.

${ }^{9}$ As cited in: ibidem, p. 125.
} 
Well, this text about the degeneration of the elite, this mocking pamphlet about the Second Polish Republic, dreaming of transatlantic ships and overseas colonies supported by an inefficient economy and backward agriculture, ripped apart in Byzantine consumption by its aristocracy, higher military strata and shady capitalists, was perceived as dangerous by the ruling class not only in 1936, but also in 1946. I might add, it is not so different even today, when what people most desire is:

Naked, in stockings, in a top hat cocked to the side,

With her nails all purpled,

With her udders painted,

An emerald monocle in one eye,

A neon advert on her thigh,

Sings an all-timer:

"Who wants some more?

Who wants some more?

Who wants some more!"

Writhing in a huge money pile

A radiant Fucking Whore

\section{J. Tuwim, Ball at the Opera ${ }^{10}$}

Ball at the opera is a spectacular, catastrophic and metaphysical poem, a poem about a world falling apart. It is also a satire, a libel, a lampoon that originated in the cabaret, and one written in brilliant language at that (this one piece can be used to teach poetics with all its metrical intricacies and the whole phonetic spectrum of our language). Nobody before Tuwim had achieved such mastery in the art of rhyme, especially masculine rhyme. However, Tuwim's doctrine, his controversial ideological message is a different thing. With all my respect for his perfect style, I find it difficult to accept his vision of Poland seen with the eyes - pardon the simplification - of Marceli Nowotko.

Tuwim had his literary inspirations, and one of them was, paradoxically, the younger and much differently ideologically predisposed Konstanty Ildefons Gałczyński, who at the time was writing his embarrassing right-wing, anti-Semitic and anti-intelligentsia, "Prosto z mostu". However, the catastrophic poems by Gałczyński, especially Koniec świata (The end of the world) and Bal u Salomona (Ball at Salomon's) must have had some influence. There was also the famous Bal manekinów (The Mannequins' Ball) by Brunon Jasieński - an outstanding poet and a great supporter of the USSR, who paid for his fascination with life in a soviet prison - whose works were printed in Russian, but Tuwim knew that language very well.

\footnotetext{
${ }^{10}$ J. Tuwim, Ball at the opera, Universitas, Cracow 2010, pp. 53-54.
} 
Finally, there is the popular poem The Twelve by Alexander Blok with an image of Christ with a rifle on his arm, setting fire to the world and making a revolution. And maybe just one more text, a more seldom mentioned one: Uwagi śmierci niechybnej (Remarks of certain death) by father Józef Baka, a "lively dying song", "a black carnival" and "dance of death", bearing a striking resemblance in its mood and linguistic effects to Tuwim's "possessed can-can".

Enchanted by Ball at the opera a certain printer from Poznan wanted to publish the piece at any cost. Tuwim called him "the first of the Gutenbergs" and gave him a different text. Known today as Kiss this arse of mine-A poem in which the author politely but decidedly asks a multitude of neighbours to kiss his arse:

And you, a fortune's whore

A perfumed whippersnapper,

Impersonating a London bore,

Wearing that spleen as if you did matter,

And you, who lives above us all,

You shat in bushes and all was fine,

Put down your nice periodical,

You all just kiss this ass of mine.

J. Tuwim, Kiss this arse of mine ${ }^{11}$

This poem, if published in full form, would have caused a greater scandal than the pathetic recent performances of visual artists, stylists and even playwrights, who by using the effective technique called "religious offence", try to promote themselves and their questionable art. Tuwim attacks everybody, justly and without any allowances, just as if he foresaw the style of Monty Python forty years later.

In 1939 Ball at the opera became a prophecy fulfilled. Tuwim left Poland at, it seems, the very last moment, and spent a few years in Brazil and the USA as an immigrant. He parted ways with other immigrants, even his closest friends because he believed that Poland's future lay in its alliance with the USSR. He believed, like many Jews remembering the Holocaust, that only Soviet communism can oppose the Nazi fascism. At the same time he saw interwar Poland as a fascist country, with ghetto benches, anti-Semitic persecutions and looming pogroms. He came back in 1946 and let the party make him their court poet - as one of his critics said: "He went to serve the idea - and got enslaved by cynical opportunists". Tuwim himself, though, believed that he was fighting the fascists who had bestially killed his depressed mother.

${ }^{11}$ Poem in which the author politely yet firmly implores the vast hosts of his brethren to kiss his arse, Poznan 1937; second edition: Biblioteka Pięciu 1937. That satirical poem was published by Andrzej Piwowarczyk, an intern in the Poznan printing office, in thirty copies, and later in five more. About this text, see i.a. M. Urbanek, op. cit., pp. 153-165. 
Yes, he did visit the balls of the secret political police and he did write poems to order. But he also saved people with a Home Army background from death sentences. It's unfortunate that he died in 1953, in the middle Stalin's reign. He did not have enough time to explain himself, to bail out, to erase his sins. To remove from his collection poems like: Do córki w Zakopanem ${ }^{12}$, (To the daughter in Zakopane) or Do narodu radzieckiego ${ }^{13}$ (To the Soviet nation).

Before he died suddenly in Zakopane, he wrote on a napkin: "Due to economic reasons I suggest turning off the eternal light, which might shine upon me"14. A funeral home worker that came to Halama was worried that the only coffins he had had a cross and/or Christ on them. Later there was the funeral filled with a stream of partly false flattery on the one hand and mostly unjust slander on the other. It seems that Staff put it best, when he claimed that Tuwim's talent verged on genius, but was a fire that burnt him down.

When I think about Tuwim I also come back to the sentence by Żeromski, who claimed that Tuwim delved so deeply into the Polish language that he came out on the other side ${ }^{15}$. There is something to it. In the end I will digress into a small personal story. As the main speaker, while attending school towards the end of the People's Republic of Poland, I recited a most beautiful passage from A Prayer, which is part of Kwiaty Polskie (Polish Flowers) during several celebratory assemblies in honour of: the workers' movement, Polish-Soviet friendship, etc. Afterwards, Solidarity came to be, and our instructors had to organize a celebration of the blessing of its banner. Not having pondered too much, they yet again had me recite: "Set ablaze the clouds above us / ring our hearts with a golden bell..."16

Then came martial law and - no, I didn't recite the same poem - instructors re-qualified as censors. Years later the words from A Prayer, "May law always mean law / And justice - justice" ${ }^{17}$ were combined to form the name of a political party. One that, incidentally, was not very keen on Tuwim's background nor his world view. Can we expect anything more from a poem?

\section{Bibliography}

Matywiecki Piotr, Twarz Tuwima, W.A.B., Warsaw 2007.

Miłosz Czesław, Traktat poetycki (1957), in: Wiersze, vol. 2, second edition, Wydawnictwo Literackie, Cracow 1986.

\footnotetext{
${ }^{12}$ See J. Tuwim, Wiersze zebrane, vol. 2, pp. 333-334.

${ }^{13}$ Ibidem, p. 335.

${ }^{14}$ M. Urbanek, op. cit., p. 287 (see also 285-288).

${ }^{15}$ Żeromski allegedly said that to A. Słonimski in a private conversation. See ibidem, p. 53.

16 J. Tuwim, Wiersze wybrane, compiled by M. Głowiński, Ossolineum, Wroclaw 1969, p. 254.

${ }^{17}$ Ibidem, p. 255.
} 
Skandal w kulturze europejskiej i amerykańskiej, B. Płonka-Syroka, M. Dąbrowska, J. Nadolna, M. Skibińska (eds.), Wydawnictwo DiG, Warsaw 2013.

Skandal w tekstach kultury, M. Ursel, M. Dąbrowska, J. Nadolna, M. Skibińska (eds.), Wydawnictwo DiG, Warsaw 2013.

Tramer Maciej, Literatura i skandal na przykładzie okresu międzywojennego, Wydawnictwo Uniwersytetu Śląskiego, Katowice 2000.

Tuwim Julian, Wiersze zebrane, vol. 1-2, Czytelnik, Warsaw 1975.

Tuwim Julian, Wiersze wybrane, complied by M. Głowiński, Ossolineum, Wroclaw 1969.

Urbanek Mariusz, Tuwim. Wylękniony bluźnierca, Wydawnictwo Iskry, Warsaw 2013.

Piotr Łuszczykiewicz

\section{The Scandalmonger: Julian Tuwim}

\section{(Summary)}

The article attempts to argue that Tuwim's personality and work can be explained by looking into his early childhood and writing. It is definitely the period inadequately explored by critics. The author discusses key moments in the poet's biography and most crucial elements of his work, paying particular attention to controversies triggered by some texts and themes in his writing. The article also focuses on the analysis of conflicts that Tuwim suffered from in his life. Tuwim's strategy of provocation is also taken under scrutiny. The article presents Tuwim's poetry as a lasting contribution to Polish literature and as a body of work which manages to resist ideological readings.

Keywords: Julian Tuwim, biography, scandal, provocation, reception 